\title{
Kin and multilevel selection in social evolution: a never-
}

\section{ending controversy? [version 1; peer review: 4 approved]}

\author{
Jos Kramer ${ }^{1}$, Joël Meunier ${ }^{1,2}$ \\ ${ }^{1}$ Zoological Institute, Evolutionary Biology, Johannes Gutenberg University Mainz, Mainz, Germany \\ 2Institut de Recherche sur la Biologie de l'Insecte, UMR 7261, CNRS, Université François Rabelais, Tours, France
}

V1 First published: 28 Apr 2016, 5(F1000 Faculty Rev):776

https://doi.org/10.12688/f1000research.8018.1

Latest published: 28 Apr 2016, 5(F1000 Faculty Rev):776

https://doi.org/10.12688/f1000research.8018.1

\section{Abstract}

Kin selection and multilevel selection are two major frameworks in evolutionary biology that aim at explaining the evolution of social behaviors. However, the relationship between these two theories has been plagued by controversy for almost half a century and debates about their relevance and usefulness in explaining social evolution seem to rekindle at regular intervals. Here, we first provide a concise introduction into the kin selection and multilevel selection theories and shed light onto the roots of the controversy surrounding them. We then review two major aspects of the current debate: the presumed formal equivalency of the two theories and the question whether group selection can lead to group adaptation. We conclude by arguing that the two theories can offer complementary approaches to the study of social evolution: kin selection approaches usually focus on the identification of optimal phenotypes and thus on the endresult of a selection process, whereas multilevel selection approaches focus on the ongoing selection process itself. The two theories thus provide different perspectives that might be fruitfully combined to promote our understanding of the evolution in group-structured populations.

\section{Keywords}

cooperation, altruism, sociobiology, group selection, levels of selection, inclusive fitness

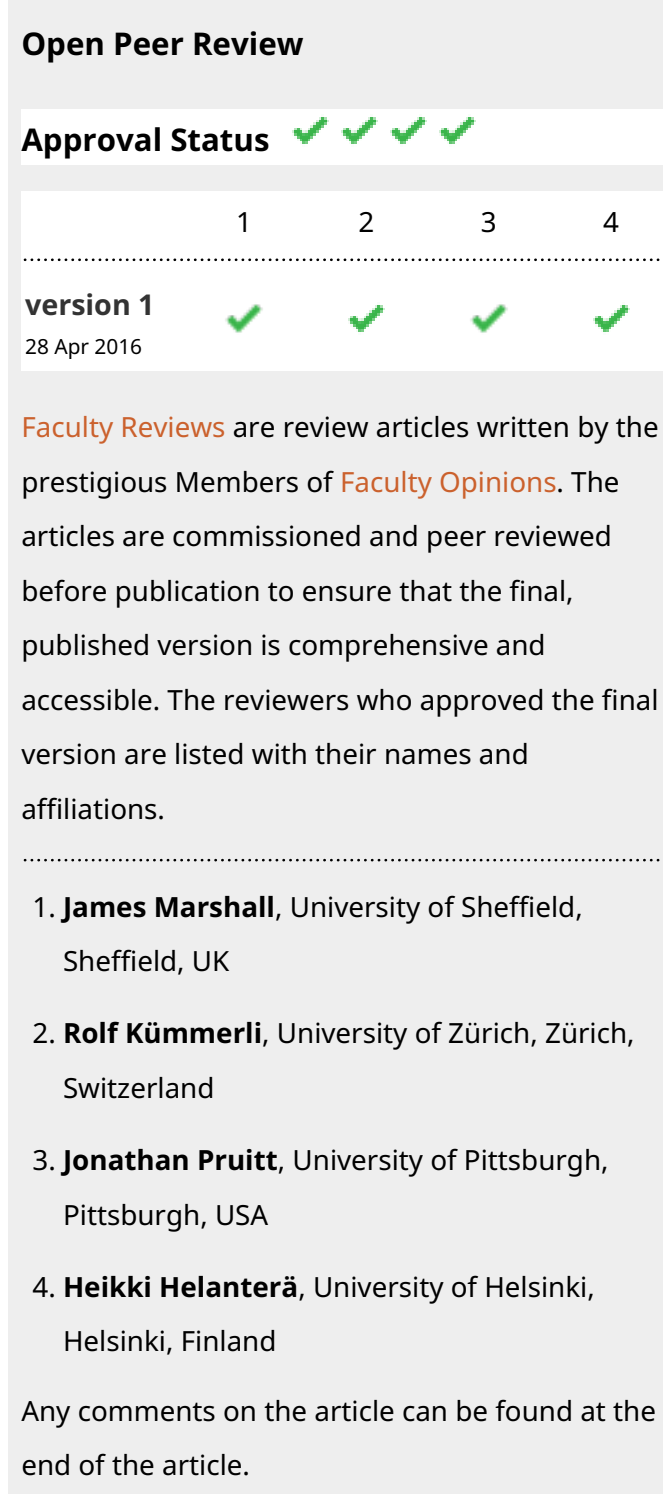

1. James Marshall, University of Sheffield,

Sheffield, UK

2. Rolf Kümmerli, University of Zürich, Zürich, Switzerland

3. Jonathan Pruitt, University of Pittsburgh, Pittsburgh, USA

4. Heikki Helanterä, University of Helsinki, Helsinki, Finland

Any comments on the article can be found at the end of the article. 
Corresponding author: Jos Kramer (JosKramer@gmx.de)

Competing interests: The authors declare that they have no competing interests.

Grant information: This study was supported by the German Science Foundation (DFG; ME4179/1-1 to JM).

The funders had no role in study design, data collection and analysis, decision to publish, or preparation of the manuscript.

Copyright: ( 2016 Kramer J and Meunier J. This is an open access article distributed under the terms of the Creative Commons

Attribution License, which permits unrestricted use, distribution, and reproduction in any medium, provided the original work is properly cited.

How to cite this article: Kramer J and Meunier J. Kin and multilevel selection in social evolution: a never-ending controversy? [version 1; peer review: 4 approved] F1000Research 2016, 5(F1000 Faculty Rev):776 https://doi.org/10.12688/f1000research.8018.1

First published: 28 Apr 2016, 5(F1000 Faculty Rev):776 https://doi.org/10.12688/f1000research.8018.1 


\section{Introduction}

Why should an individual cooperate to benefit others? This question pinpoints one of the central theoretical problems of sociobiology ${ }^{1-3}$. Cooperative behaviors such as altruism (an action that benefits others at one's own expense) would reduce the fitness of the performer relative to selfish individuals that do not perform the behavior, and hence should be selected agains $\mathrm{t}^{4-6}$. However, this expectation is in striking contrast to the ubiquity of cooperation in nature, which occurs among 'simple' microorganisms $s^{7,8}$ and within highly complex eusocial societies alike?.

Kinship and group selection are two key concepts of modern sociobiology that have been proposed to help resolve this apparent conundrum ${ }^{1,6}$. Despite their common origin in the writings of Charles Darwin (cf. 10), the developments of these two concepts in the modern kin and multilevel (or group) selection theories followed diverging paths and fueled a persisting and often heated debate about their relevance and usefulness in the study of social evolution (e.g. 11-13). Here, we provide a concise introduction to the two theories and the controversy surrounding them as well as highlight the complementarity of the approaches typically taken by their proponents. To this end, we first separately introduce the two theories and then point to the roots of the controversy. We subsequently review two important aspects of the current debate in more detail: the presumed formal equivalency of the two theories and the notion of group adaptation. We overall suggest that these issues illustrate the complementary nature of the perspectives offered by the kin selection and multilevel selection theories.

\section{Kin and multilevel selection theories in a nutshell Kin selection theory}

Interacting organisms may have an evolutionary incentive to help each other (or at least to hurt each other less) if they share genes, and the magnitude of this incentive should increase with the degree of relatedness between them; this is the central tenet of William D. Hamilton's inclusive fitness theory ${ }^{14-16}$ (the term kin selection theory was coined by John Maynard-Smith ${ }^{11}$ and is here used as a synonym for 'inclusive fitness theory' to comply with its conventional use). This tenet is encapsulated in a very simple form in Hamilton's rule, which states that a (gene for a) social behavior is favored by natural selection if $r b-c>0$, where $c$ is the fitness cost to the individual performing the behavior, $b$ equals the fitness benefit to the recipient(s), and $r$ is the genetic relatedness between them ${ }^{14,15}$. The rule thus formalizes the realization that natural selection acts not only through direct effects of a behavior on the actor's own fitness (often measured as reproductive output) but also through indirect effects on the fitness of the actor's relatives (that have an above-average probability of sharing the actor's genes, including the one[s] that cause the social behavior in question) ${ }^{1}$. Moreover, it provides a potential solution to the central problem of sociobiology, as it shows that even costly social behaviors can be favored by natural selection as long as the direct costs are outweighed by a sufficient amount of indirect benefit to sufficiently closely related individuals (Figure 1) ${ }^{17}$. Note, however, that the application of Hamilton's rule - and thus kin selection theory-is not restricted to altruistic behaviors: $r b$ and $-c$ represent, respectively, the indirect and the direct fitness consequences of any character of interest and hence can both be positive, negative, or zero ${ }^{18}$. Accordingly, they can also represent mutually beneficial (both fitness components positive), spiteful (both components negative), or selfish (direct component positive and indirect component zero or negative) behaviors.

Alongside Hamilton's rule, the concept of inclusive fitness is the second central element of kin selection theory. An organism's inclusive fitness is defined as the sum of its direct (Darwinian) and indirect fitness components (Figure 1). The latter is calculated as the relatedness-weighed sum of those effects on the fitness of other individuals for which the organism is causally responsible ${ }^{14,17}$. Inclusive fitness is thus an actor-centric approach that examines how a focal individual influences its own fitness and that of its social partners ${ }^{19}$. Hamilton ${ }^{14}$ also suggested an alternative and (by now) increasingly used approach to account for direct and indirect fitness effects (e.g. 20-22): the neighbor-modulated fitness (sometimes referred to as personal or direct fitness). The two approaches differ in how the indirect component is conceptualized: in contrast to inclusive fitness, neighbor-modulated fitness is a recipientcentric approach and thus examines how social partners influence the fitness of a focal individual ${ }^{19}$ (Figure 1). The two approaches are usually seen as equivalent, as they predict the same overall response to natural selection ${ }^{18}$ (but cf. 23,24). The inclusive fitness approach, however, comes with one significant conceptual advantage: in principle, an individual is causally responsible for both its direct and indirect fitness and hence can control its inclusive fitness. Thus, natural selection might favor organisms that act as if they are attempting to maximize their inclusive fitness ${ }^{14,25-27}$ (but cf. 28,29). The possibility of conceptualizing individuals as maximizing agents (an optimality approach ${ }^{30}$ ) greatly facilitates the linking of theoretical and empirical research and has been central to the study of adaptation in behavioral and evolutionary ecology ${ }^{19}$.

Over the last five decades, kin selection theory has been extensively developed and generalized (e.g. 20,31-35; see 22,23 for book-length treatments) beyond the limited scope of Hamilton's original formalization ${ }^{14-16}$. For instance, Hamilton originally defined relatedness as a genealogical measure of shared ancestry ${ }^{14}$ but quickly realized that this is only one (albeit by far the most frequent) way of generating the above-average genetic similarity among individuals that ultimately drives the evolution of many cooperative behaviors ${ }^{16,31,36}$. In contemporary discussions, relatedness is accordingly more broadly defined (e.g. 23,24) and encompasses any genetic similarity, regardless of whether it arose by common descent or by other means such as green-beard effects ${ }^{37,38}$. Moreover, the generalization of kin selection theory resulted in the development of general versions of Hamilton's rule (most notably on the basis of the Price equation; see below and 34) that-unlike the original version-make no assumptions such as weak selection or additivity of fitness payoffs (see also 18,39,40). In these general versions, the cost-benefit parameters no longer denote simple fitness payoffs of social interactions but rather partial regression coefficients that quantify the overall statistical association among an organism's phenotype/genotype, its fitness, and the phenotype/ genotype of its social partners ${ }^{17,41}$. Concomitant with its generalization, kin selection theory has become the dominating framework for the explanation of social behavior from an evolutionary viewpoint (e.g. 42,43). Its most prominent empirical prediction, namely that social behavior should correlate with relatedness, has been 

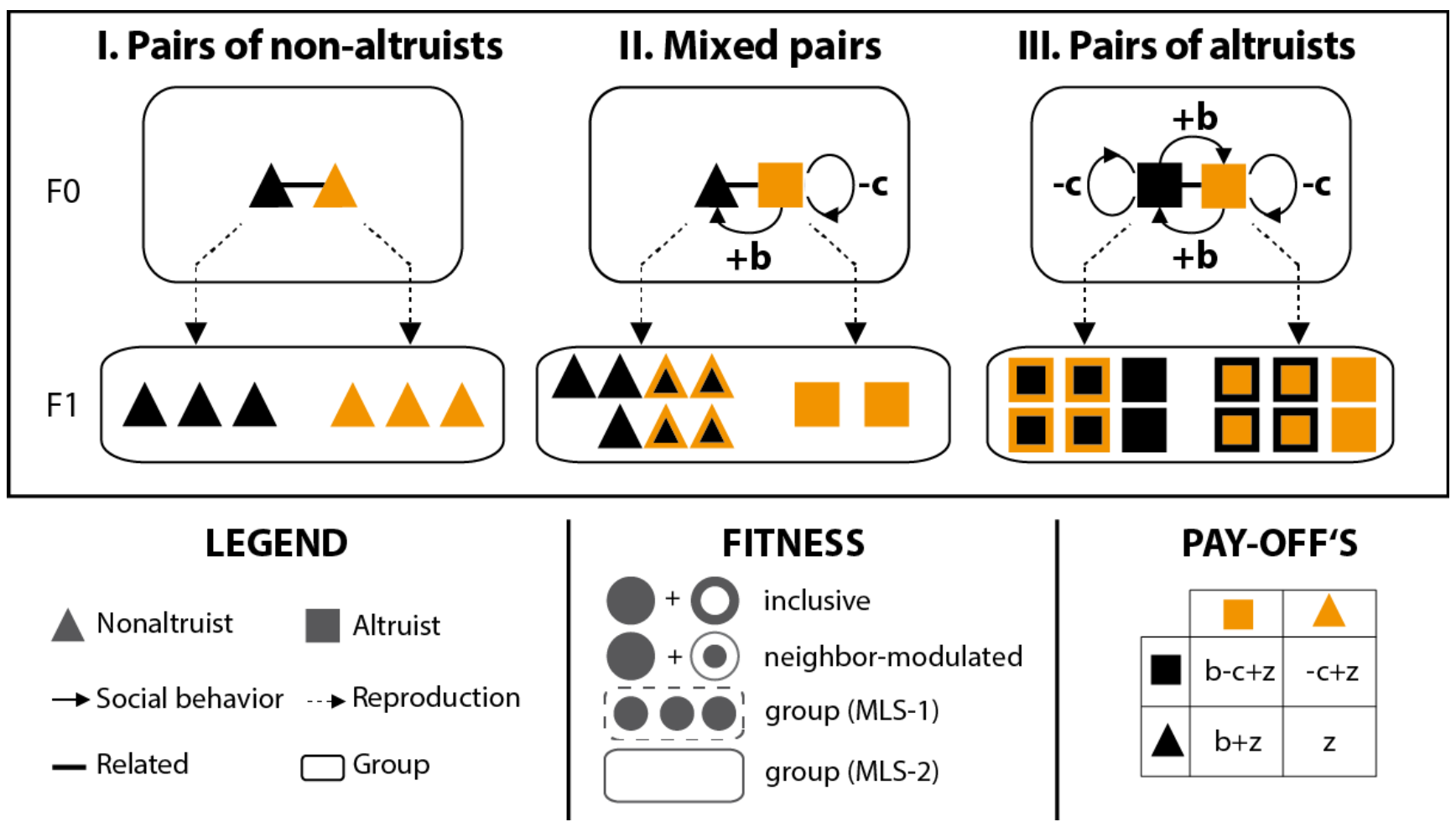

Figure 1. Social interactions in a group-structured population. In this example, non-altruists and altruists (symbolized by triangles and squares, respectively; see the legend for details) form (I) pairs of non-altruists, (II) mixed pairs, and (III) pairs of altruists. Altruists and nonaltruists do not share the gene(s) causing the altruistic behavior but are overall related (i.e. genetically similar with respect to other traits). Upon reproduction, the (F1) progeny of each pair forms an independent group. Non-altruists do not express social behaviors and reproduce according to a baseline fitness (here arbitrarily fixed at $z=3$ ). In contrast, altruists (unconditionally) confer a fitness benefit $(b=4)$ onto their partner at a cost $(c=1)$ to themselves. Although altruists incur a direct fitness cost, they benefit indirectly from assisting their partner and hence overall increase their inclusive fitness (see the fitness box for an illustration: inclusive fitness is composed of a direct [unicolored symbols] and an indirect [symbols framed in the same color] component). Similarly, their neighbor-modulated fitness is increased if they are assisted by their partner. However, altruists have a relative fitness disadvantage within mixed pairs because they increase the fitness of their non-altruistic partner at a cost to themselves and without receiving help in return (see pay-offs box for details). Hence, altruism can be disadvantageous even within groups of overall related individuals (precisely if they do not share the altruistic gene). In contrast, uniform pairs of altruists produce more offspring than mixed groups or groups of non-altruists (they hence have a higher group fitness in an MLS-1 framework; the group fitness in an MLS-2 framework corresponds to the number of groups produced and is here the same for all pairs). Positive assortment of altruists (e.g. due to limited dispersal) reinforces this 'group-advantageous' effect and can explain the evolution of cooperation in the long run.

supported across diverse taxa (the equally important impact of the costs and benefits received less attention, but see 44,45), and kin selection theory has greatly contributed to our current understanding of a variety of biological phenomena such as dispersal, reproductive skew, and queen-worker conflicts in eusocial insects ${ }^{46,47}$.

\section{Multilevel selection theory}

The central tenet of multilevel (or group) selection theory conveys that selection not only acts on individuals but can act (simultaneously) on multiple levels of biological organization, including cells and/or groups ${ }^{48}$. This view suggests that even if behaviors that benefit other individuals are selectively disadvantageous at the level of the individual, they might still evolve if they are advantageous at - and hence selected for on - a higher level of the biological hierarchy (e.g. on the group or colony level) ${ }^{6,48}$. Altruism, for instance, is costly for the altruistic individual, but groups containing a higher proportion of altruistic individuals usually have a competitive advantage over groups that are composed mostly of selfish individuals (e.g. because altruistic groups are more productive or superior in direct confrontations). In such situations, altruism can evolvedriven by a process of selection between groups-even against the background of selection favoring selfishness within each group (e.g. 49,50). This is the potential solution of the central problem of sociobiology from a multilevel perspective (Figure 1). The applicability of multilevel selection theory, however, is not limited to situations in which selection pressures on different hierarchical levels are opposing. Multilevel selection approaches more generally examine the direction and strength of (naturally occurring or experimentally applied) selection pressures on multiple hierarchical levels, investigate the mediators (e.g. indirect genetic effects ${ }^{51-53}$ ) and magnitude of their respective contributions to total evolutionary change $\mathrm{e}^{50,54,55}$, and explore effects of selection on group traits ${ }^{56}$. 
Interestingly, there is currently no unanimously accepted formal theory of multilevel selection (e.g. 57-60) apart from the broad consent that defines group selection as natural selection based on the differential survival and reproduction of groups ${ }^{6,51,61}$ (but cf. 54). As a result, both individuals and groups can be found as focal units of attention (Figure 1) in multilevel selection approaches. Similarly, the definitions of group fitness and group vary among studies depending on whether they aimed at explaining the changing frequency of different types of organisms in a group-structured population or at explaining the changing frequency of different types of group in a meta-population of groups. In the first case, group fitness is often defined as the average (or total) fitness of its constituent organism (multilevel-selection-1, or $M L S$-1; Figure $1^{62-64}$ ), and the group as a set of interacting individuals that influence each other's fitness, but not the fitness of individuals outside the group, with respect to a particular trait (trait-group ${ }^{49,61}$; see 48 for a discussion of this concept). In the second case, group fitness is defined as the expected number of offspring groups ( $M L S$-2; individual fitness is then usually defined separately and on a different timescale $\left.{ }^{62-64}\right)$. MLS-2 approaches often explicitly incorporate group-level events such as fission or extinction and thus assume that groups of individuals undergoing such group-level events can be identified in the population ${ }^{64}$. Groups are consequently more narrowly defined as geographically discrete, multigenerational, and reproductively isolated demes (Figure 1) $)^{48}$.

It is important to note that MLS-1 and MLS-2 approaches are not equivalent, as they relate to different natural processes ${ }^{48}$ (but cf. 58). In an MLS-1 scenario, groups 'merely' generate the population structure that affects the fitness of individuals. Hence, groups can propagate by producing individuals as long as these individuals form groups themselves at some stage of their life (e.g. after blending in a common mating pool). In contrast, groups need to reproduce in an ordinary sense in an MLS-2 scenario (i.e. by producing more groups $)^{48}$. Though sometimes seen as fostering confusion (e.g. 58,65), the difference between MLS-1 and MLS-2 also provides an intriguing diachronic perspective on 'major transitions' in evolution-and thus on the evolution of the biological hierarchy itself-as such transitions involve a temporal shift from MLS-1 (groups of individuals) to MLS-2 (groups as individuals) ${ }^{66-69}$.

Despite its controversy-plagued history (see below), the multilevel selection theory has undergone a resurgence of interest in recent years (e.g. 6,12,58,70-72; see 48 for a book-length treatment). This is because it has provided novel perspectives on a variety of issues such as parasitic virulence ${ }^{73}$, cultural group selection in humans (that is often envisioned as the outcome of warlike confrontation $)^{74,75}$, or the 'major transitions' in evolution ${ }^{48,69}$.

\section{The controversy}

\section{A brief history}

The controversy surrounding the theories of kin and multilevel selection has a long and turbulent history (detailed, e.g., in $1,24,48,61,76)$. Until the second half of the last century, many biologists did not clearly distinguish between different levels of selection, and it was often uncritically assumed that group selection would easily prevail over individual selection (e.g. 77) or that individual selection alone would foster adaptations 'for the good of the group' (e.g. 78). It was the rebuttal of these 'naïve' assumptions (though not of the theoretical plausibility of group-level thinking per se; cf. 6) that widely led to the rejection of group selection as a significant evolutionary force ${ }^{79}$. Notably, kin selection theoryalong with other theoretical frameworks such as evolutionary game theory ${ }^{80}$ and selfish gene theory ${ }^{37,81}$ — was initially developed as an alternative to group selection (e.g. 11,15), which likely contributed to an increasing polarization in disfavor of arguments based on group-level thinking (e.g. 37).

However, the demise of group selection was only temporary. Subsequent studies dropped the 'naïve' assumption of the unconditional superiority of group selection and instead acknowledged that selection within groups often undermines selection among groups (e.g. 49,82-84). Building on this premise, trait-group models suggested that group selection can drive evolutionary change even when opposed by within-group selection and that a periodical blending of groups (e.g. in a common mating pool) can prevent the seemingly inevitable fixation of selfish types within groups ${ }^{49,84}$. Moreover, empirical studies demonstrated that experimentally applied group selection can drive evolutionary change (e.g. 85-87; reviewed in 59,88) and argued that early models had restricted the applicability of group selection by deploying unrealistic assumptions, such as the notion that group and individual selection are always diametrically opposed (reviewed in 6,51). Interestingly, Hamilton himself showed that multilevel selection was formally equivalent with his theory of inclusive fitness (31, see next section), suggesting that the two theories simply outline different perspectives on the same natural processes. In some minds, this realization closed the debate, as the choice between the two theories seemed to have become a mere matter of personal taste. But far from it, the relationship between kin and multilevel selection remained controversial.

Over the last four decades, the group selection controversy has lost little of its initial momentum and continues to polarize opinions fueled by semantic debates (reviewed in 12,65,70) and, ultimately, the different implications the two theories seem to have for the evolution and self-perception of our own species ${ }^{89-91}$ (see also 92 and associated responses). Accordingly, some biologists contest the usefulness of multilevel selection in the study of social evolution in general ${ }^{12,65}$, whereas others call for a reframing of the theoretical foundations of sociobiology from a multilevel perspective ${ }^{6}$. Nevertheless, the focus of the controversy has shifted away from the question of whether group selection occurs at all and now mainly revolves around (the consequences of) its presumed formal equivalence with kin selection theory and the question of whether group selection can lead to (group) adaptation. These are the two topics we will discuss below.

Kin and multilevel selection: formally equivalent theories? Most biologists consider kin and multilevel selection formally equivalent (e.g. 24,40,61,93,94), but this view is not universally accepted and the number of dissenting voices has recently grown (e.g. 95-102). What, then, is the basis for the formal equivalency of the two approaches, and why is it still controversial?

On a practical level, the compatibility of kin and multilevel selection relies on the fact that both theories require positive assortment 
of (genetically) similar individuals for cooperative behaviors to evolve $(31,103,104$; see $105-108$ for examples). From a multilevel perspective, positive assortment increases the scope for betweengroup selection, as it will make groups internally more homogeneous and thus reduce the potential for within-group selection (Figure 1$)^{48}$. From a kin selection perspective, positive assortment ensures that costly social behaviors such as altruism are preferentially directed toward individuals that show the behavior themselves $^{31}$. This directionality is crucial: altruistic traits are selectively disadvantageous even when directed at otherwise (genetically) very similar non-altruists (Figure 1) and thus can evolve only if altruists sufficiently often interact with other altruists, thereby increasing their average inclusive fitness over that of non-altruists ${ }^{31}$. In practical terms, the compatibility of kin and multilevel selection hence conveys that individuals expressing social behaviors (such as altruism) have a higher inclusive fitness than selfish individuals, whenever selection between groups is stronger than selection within them, and vice versa ${ }^{109}$.

On a theoretical level, the compatibility of kin and multilevel selection is conventionally understood to predicate that group selection models can always be recast in terms of inclusive fitness ${ }^{39,93}$. This formal equivalency is usually inferred by using an equation developed by George C. Price ${ }^{110,111}$ that expresses the intergenerational, population-level response to natural selection in a heritable trait as the covariance, taken over all individuals within the population, between an individual's trait and its fitness (here measured as its fecundity; e.g. 31,40,94). The Price equation allows partitioning the evolutionary change into its direct and indirect components and can be used to derive Hamilton's rule (the kin selection approach; ${ }^{18,22,34,36}$ ). However, it also lends itself to partition the evolutionary change into effects at the individual and group levels ${ }^{22,31,40,48,94,111}$. Hence, kin and multilevel selection are formally equivalent when formulated as alternative decompositions of the Price equation, as both approaches make it possible to correctly compute the total evolutionary change. The approaches differ merely in how this change is partitioned and thus offer different, potentially complementary ways of viewing evolution in structured populations ${ }^{31,40,94,112}$. Two points, however, deserve a closer examination: firstly, the above-described decomposition of multilevel selection applies only to scenarios of the MLS-1 type (as group fitness is defined as average individual-level fitness of group members $;^{48}$ ). Secondly, the multilevel partitioning requires individuals to be nested in non-overlapping groups; the kin selection approach comes with no such requirement and thus is arguably more general within the Price framework ${ }^{24,31,48}$.

Albeit most commonly used in theoretical studies, the Price framework is not the only approach to study multilevel selection. An alternative approach (that is often adopted in empirical studies; e.g. $55,113,114)$ is offered by contextual analysis ${ }^{48,50,115}$. Like the Price equation, contextual analysis partitions the change due to natural selection (in MLS-1 scenarios, ${ }^{48}$ ) into individual and group effects; but unlike the Price equation, it detects group selection only if group effects on fitness remain even after controlling for individual effects. Contextual analysis thus accommodates a classic criticism against the multilevel partition of the Price equation, which can detect a component of between-group selection even in non-social contexts (i.e. when the evolution of the population can be predicted without taking group structure into account), and hence might not always accurately reflect the true causal effect of group selection ${ }^{48,115}$. However, contextual analysis has problems of its own, as it detects group selection when there is no variation in fitness among groups (e.g. because they all have the same productivity), but individual fitness depends on their ranking within the group (soft selection; ${ }^{48,50,115}$; but cf. 59). Owing to these problems, it is still controversial which approach is better suited to study multilevel selection (e.g. 48,58-60,116,117; see also 99,118,119). Note however that contextual analysis is formally very similar to modern kin selection models that are based on neighbor-modulated fitness. This supports the conjecture of an equivalency of kin and multilevel selection, as the two approaches seem inter-translatable even when multilevel selection is studied by using contextual analysis rather than the Price equation ${ }^{1,30}$.

Though suggested by both the Price equation and contextual analysis, the formal equivalency of kin and multilevel selection remains controversial (e.g. 95-99). Most critics seem to reject (aspects of) the generalization of kin selection theory and instead contrast specific, narrowly defined formulations of kin selection with more general approaches to multilevel selection (e.g. 96,99,100,102). For example, Wilson and Hölldobler ${ }^{100}$ rejected the broad definition of relatedness, arguing that it leads to a departure from the earlier and heuristically very useful narrow definition of kin selection. As a consequence, it can be argued that kin selection is only a special case of multilevel selection because relatedness (i.e. genetic similarity) can occur without strict kinship and hence evolution can occur by group selection in the absence of selection among narrow-sense kin (for instance, if group selection acts on green beards) ${ }^{1}$. Similarly, Van Veelen and colleagues ${ }^{96,99}$ (see also 95,97) rejected attempts to generalize kin selection and then contrasted multilevel selection with a specific (rather than a general) version of kin selection in which the cost-benefit parameters of Hamilton's rule denoted fitness payoffs (rather than partial regression coefficients). They showed that this kin selection approach can lead to incorrect predictions if the payoffs are non-additive (see also 120) and hence concluded that multilevel and kin selection are not equivalent. However, they compared a specific formulation of kin selection with their general formulation of multilevel selection and hence arguably could not refute assertions of the equivalency of the two theories that are based on general formulations of kin selection (cf. 17).

Interestingly, these rejections of the general formulation of kin selection $^{99,121}$ (see also 122,123) relate to a more extensive debate that was initiated by a high-profile charge of Nowak, Tarnita, and Wilson against the value of inclusive fitness theory in explaining the evolution of eusociality ${ }^{101}$. This partly philosophical debate revolves around the question of whether the cost-benefit parameters in general formulations of Hamilton's rule allow a causal interpretation at all. As these parameters denote partial regression coefficients, they can depend on relatedness ${ }^{124}$ and population gene frequency, which can, for instance, lead to the counterintuitive result that a social behavior satisfies Hamilton's rule at a low, but not at a high, frequency ${ }^{13}$. Whereas critics consequently deny the general formulations of Hamilton's rule any explanatory power and claim that they cannot accurately describe the evolutionary dynamics of any given system (e.g. 13,101,121,125), others argue that they serve as a unifying principle that provides a 
super-ordinated framework for interpreting the results of otherwise disparate models in a general terminology (e.g. 18,39). Overall, this debate reveals that the formal equivalency of kin and multilevel selection (somewhat obviously) holds only if equally general formulations of the two theories are pitted against each other and that the issue at the heart of the debate really is the question of whether such general formulations make sense from a heuristic perspective (e.g. 13,18,19,101,125-128; see 17,41 for in-depth reviews). Indeed, the question of whether and when general versions of Hamilton's rule (and thus kin selection theory) provide a better/worse causal (rather than statistical) representation of the evolutionary process than the corresponding general approaches to multilevel selection (see also Conclusions section) might provide a fruitful avenue for future discussions.

Another line of reasoning against the equivalency of kin and multilevel selection suggests that even generalized formulations of kin selection cannot account for the long-term effects of events on the group level ${ }^{57,95,98}$. Group-level events such as fission, fusion, or extinction often occur asynchronously, and Simon and colleagues ${ }^{57}$ recently suggested that group selection should consequently be thought of (and analyzed) as an asynchronous, continuous-time process that is shaped by the combined, long-term effects of such group-level events. On this basis, they argued that although kin and multilevel selection are often equivalent when only one time interval between two group-level events is analyzed, they would almost never be equivalent in a dynamical setting because kin selection approaches could not account for the asynchronous nature of the group-level events ${ }^{57,98}$ (see also 129). Interestingly, they also suggest that the long-standing disagreement over the equivalency of kin and multilevel selection is based on oversimplified models of multilevel population dynamics and an inappropriate definition (via the Price equation) of group selection ${ }^{57,98}$ : in its usual form, the Price equation traces the evolutionary change only over short periods (see above), assumes that all relevant processes such as reproduction or mass dispersion occur at a discrete set of time points, and is restricted to MLS-1 scenarios in which group-level events (other than mass dispersion) do not feature explicitly ${ }^{57,98}$. Thus, the Price equation (and contextual analysis) might be insufficient to capture all relevant aspects of the selection among groups.

Overall, the last word on the equivalency of kin and multilevel selection has surely not been spoken, as the partly philosophical character of the debate prevents it from being settled by theoretical or empirical results alone (cf. ${ }^{17}$ ). However, even if it would turn out that the equivalency is untenable in some situations, kin and multilevel selection will surely continue to occupy largely overlapping domains, leaving evolutionary biologists with both the blessing and the curse of the existence of multiple theoretical frameworks to study social behavior.

\section{Does group selection lead to group adaptation?}

One fundamental issue that triggered the initial rejection of group selection was the (then naïvely alleged) claim that it can foster group adaptation (i.e. promote the evolution of traits 'for the good of the group') ${ }^{6}$. Although an evolutionary response to group selection has by now been demonstrated in a variety of laboratory and field studies (e.g. 85,130-132), the claim that it can foster group adaptation (or any adaptations at all) remains highly controversial ${ }^{12,65}$.
Recently, Pruitt and Goodnight ${ }^{56}$ reported that natural colonies of the social spider Anelosimus studiosus are characterized by a site-specific mixture of 'docile' and 'aggressive' individuals and showed that experimentally constructed colonies with compositions mimicking the naturally occurring mixtures survived in the field but that colonies with deviating compositions perished. Experimental colonies with a perturbed composition that had survived at a 'foreign' site had shifted their composition toward a mixture that would have been optimal at their native site rather than toward the locally optimal mixture. Considering these results, Pruitt and Goodnight suggested that the composition of colonies differs between sites because of site-specific group selection and-as it is optimized to promote long-term colony survival at the native siteconstitutes a group adaptation ${ }^{56}$. This latter conclusion, however, did not go unchallenged ${ }^{133-135}$. Grinsted and colleagues ${ }^{134}$ criticized that individual-level selection was not ruled out as an alternative explanation of Pruitt and Goodnight's results, and Smallegange and Egas ${ }^{133}$ indeed developed an environmental threshold model to explain Pruitt and Goodnight's observations at the individual rather than the group level. Finally, Gardner ${ }^{135}$ argued that colony composition is unlikely to maximize colony fitness and thus rejected the claim that the site specificity of colony composition constitutes a group adaptation.

Do the results of Pruitt and Goodnight ${ }^{56}$ thus provide no evidence for a group-level adaptation after all? The answer depends on the definition of 'group adaptation'. In a kin selection framework, adaptations are regarded as occurring at the level of the individual organism and to maximize an individual's inclusive fitness ${ }^{19,135,136}$. By analogy, group adaptation is thus understood as a process that is driven by between-group selection and optimizes phenotypes for the purpose of group fitness maximization ${ }^{135,136}$ (see also 137). This optimization process, however, is typically compromised by within-group selection because of conflicts among group members and thus will be favored by natural selection only if these conflicts are either absent (as for instance in clonal groups) or completely suppressed $^{136}$ (but cf. 138,139), for example, through mechanisms such as fair meiosis ${ }^{140,141}$ or worker policing ${ }^{140,142}$. Accordingly, group adaptations are expected to occur only rarely in nature, where their demonstration would require showing that within-group conflict is absent and group fitness is maximized ${ }^{135,136}$. Pruitt and Goodnight ${ }^{56}$ did not assess within-colony conflict and thus arguably provide no conclusive evidence for group adaptation according to the above definition - a view that is embraced by all critics of their interpretation $^{133-135}$.

However, a different approach to group (and individual) adaptation is conventionally taken in a multilevel selection framework (e.g. 109,143,144). In accordance with the kin selection framework, a process would be defined as group adaptation if the trait frequency evolves toward (or has settled down at) the group optimum (i.e. the trait frequency that is predicted to evolve when only between-group selection is at work). Likewise, a process would be defined as individual adaptation in both frameworks if the trait frequency is driven by within-group selection only and hence evolves toward (or has settled down at) the individual optimum. However, differences between the kin and multilevel selection frameworks emerge if within- and between-group selection are aligned or if the metapopulation evolves toward (or has settled down at) a 
compromise (i.e. an intermediate trait frequency) ${ }^{61,109}$ (see also 1). In these situations, the (outcome of the) process would be called an individual adaptation in the kin selection framework, where adaptations are generally considered to occur at the level of the individual irrespectively of the strength of between-group selection ${ }^{136,145}$. In contrast, such compromises are often considered group adaptations in a multilevel selection framework, especially if they are (predominantly) driven by between-group selection ${ }^{109,144}$. Accordingly, while mechanisms of conflict suppression such as policing and punishment are a prerequisite of group adaptation in the kin selection framework, they are often considered group adaptations themselves in a multilevel selection framework ${ }^{6,84}$. In a reply to their critics, Pruitt and Goodnight adhere to this latter view and argue that the group-level trait 'colony composition' is shaped by site-specific group selection and hence constitutes a group adaptation ${ }^{143}$.

This recent debate about the implications of Pruitt and Goodnight's findings ${ }^{56}$ sheds light on a clear distinction between the kin and multilevel selection frameworks. The kin selection approach typically grants the individual priority as an evolutionary agent because it appears as an adaptive unit and consequently allows a clearcut distinction between individual and group adaptations even if selection acts on both the within- and between-group levels ${ }^{136,145}$ (but cf. 1,61,109). In contrast, the multilevel selection approach allows such a clear distinction only in special cases (namely if selection acts only on one level) but places more emphasis on the fact that the realized frequency of a social trait is usually a compromise of different selection pressures ${ }^{109,143}$. Moreover, the multilevel selection approach allows for situations in which selection pressures on the individual and group levels are (at least to some extent) aligned. This might be the case where collective traits (e.g. the superstructure of waterproof rafts built by fire ants through self-assembly ${ }^{146}$ ) simultaneously promote the survival of the group and directly benefit the individuals within it. We suggest that both approaches may provide important insights into our understanding of social evolution and that, instead of focusing on their (semantic) differences, a more fruitful approach to the adaptiveness of social groups might be to ask how well adapted a particular social group is relative to the (theoretical) ideal of a conflict-free group ${ }^{1}$ (see also 136,147). Moreover, it is important to note that although the kin selection approach to group adaptation is more restrictive than the multilevel selection approach, both in principle allow for group adaptation. Thus far, the formal demonstration of group adaptation (i.e. a group-optimal and conflict-free outcome) according to Gardner and Grafen's kin selection-based definition ${ }^{136}$ is still pending. However, elaborate group-level traits such as the dance-language of honey bees ${ }^{148}$ are good candidates that might live up to the definition of group adaptation within both frameworks.

\section{Conclusions}

Kin and multilevel selection are two key concepts of modern sociobiology that provide different perspectives on the evolution of social behaviors. Unfortunately, these approaches are often pitted against each other in a seemingly endless (and largely semantic) debate that arguably impedes scientific progress ${ }^{91}$ and prevents the benefits of the different perspectives from being harnessed.
Most biologists prefer kin selection over multilevel selection approaches as a matter of habit or personal taste ${ }^{12,65}$, and this preference seems partly justified as kin selection approaches have received more theoretical attention (and are hence highly versatile) (2,23 $^{20}$ and have been put to work in more empirical applications ${ }^{17,46,149}$ (but note that the widespread acceptance of their formal equivalency implicates that empirical evidence for one theory cannot be used as evidence against the other). However, we believe that a bipartisan view on the kin and multilevel selection theories might ultimately prove more fruitful. After all, there might be situations in which one approach provides a more accurate representation of the causal structure of social interactions despite their (presumed) equivalency as statistical decompositions of evolutionary change ${ }^{17,150}$. For example, it might be more causally apt to describe the selection pressures on a segregation distorter allele that has negative effects on the fitness of its bearer in terms of multilevel selection (i.e. as opposing selection pressures at the gene and individual levels). Conversely, it might be more causally apt to describe the selection on cooperative behavior in pairwise interactions between related individuals in terms of kin selection, especially if those pairs are ephemeral and form only for the duration of the social interactions ${ }^{17}$. More generally, kin selection might provide a more accurate representation of the causal structure of social interactions than multilevel selection where fitness pertains to individuals in the first instance (and group fitness is a simple function of the fitness of its constituent individuals; see also 22,48), whereas the opposite might be true where fitness pertains to the whole group in the first instance (and individual fitness is determined by group fitness $)^{150}$. Such considerations of causal aptness might help to explain why multilevel selection was readily accepted for the study of major transitions ${ }^{48,69}$ but only slowly establishes itself in the field of behavioral ecology, in which social interactions are often studied in ephemeral 'groups' of genealogical kin $^{42}$. It is noteworthy that considerations of causal aptness seem less clear in the case of eusocial systems (such as ants, termites, and some species of bees and wasps; cf. 48) and that exactly these systems take center stage in the controversy surrounding the kin and multilevel selection theories (e.g. 100,101,126,127,151).

Interestingly, kin and multilevel selection approaches might ultimately prove to be very useful exactly when applied to the same system. Kin selection analyses often follow an optimality ('adaptationist') approach and accordingly try to identify the phenotype(s) with the highest overall fitness to extrapolate where a population will eventually stabilize ${ }^{18,30}$. The strength of kin selection (as a driver of evolutionary change over the course of one or multiple generations), however, is rarely reported ${ }^{30}$. In contrast, multilevel selection approaches often follow an 'evolutionary change' approach and examine how a population will change its current configuration (for example, depending on the strength of within- and between-group selection or in response to an applied selection pressure $)^{30,59}$. The optimal phenotype, however, is typically not identified in multilevel selection studies ${ }^{30}$. The two perspectives opened up by the kin and multilevel selection approach, respectively, seem to be highly complementary ${ }^{30,59}$. Experimental studies already began to harness the translatability of the two approaches (e.g. 107,108,152,153). However, we still eagerly await studies that 
make use of the full potential of their complementarity by combining both the 'evolutionary change' and 'adaptationist' perspective and the methods that come along with them. We believe that such studies would go a long way toward gaining a deeper understanding of the processes that ultimately drive the evolution of social behaviors in structured populations.

Competing interests

The authors declare that they have no competing interests.

\section{Grant information}

This study was supported by the German Science Foundation (DFG; ME4179/1-1 to JM).

The funders had no role in study design, data collection and analysis, decision to publish, or preparation of the manuscript.

\section{Acknowledgements}

We thank Susanne Foitzik, James A.R. Marshall, Heikki Helanterä, Jonathan Pruitt, and Rolf Kümmerli for their helpful comments on an earlier version of this manuscript.
1. Foster KR: A defense of sociobiology. Cold Spring Harb Symp Quant Biol. 2009; 74: 403-18.

PubMed Abstract | Publisher Full Text

2. Wilson EO: Sociobiology: The new synthesis. Harvard University Press, 1975. Reference Source

3. Sachs JL, Mueller UG, Wilcox TP, et al.: The evolution of cooperation. Q Rev Biol. 2004; 79(2): 135-60.

PubMed Abstract | Publisher Full Text

4. West SA, El Mouden C, Gardner A: Sixteen common misconceptions about the evolution of cooperation in humans. Evol Hum Behav. 2011; 32(4): 231-62. Publisher Full Text

5. West SA, Griffin AS, Gardner A: Evolutionary explanations for cooperation. Curr Biol. 2007; 17(16): R661-72. PubMed Abstract | Publisher Full Text

6. F Wilson DS, Wilson EO: Rethinking the theoretical foundation of sociobiology. Q Rev Biol. 2007; 82(4): 327-48.

PubMed Abstract | Publisher Full Text | F1000 Recommendation

7. Foster KR: Social behaviour: in microorganisms. In Genes, ecology and evolution. (Székely T, Moore AJ \& Komdeur J), Cambridge University Press, 2010; $331-356$

Publisher Full Text

8. F Drescher K, Nadell CD, Stone HA, et al:: Solutions to the public goods dilemma in bacterial biofilms. Curr Biol. 2014; 24(1): 50-5.

PubMed Abstract | Publisher Full Text | Free Full Text | F1000 Recommendation

9. Hölldobler B, Palmer JM, Moffett MW: Chemical communication in the dacetine ant Daceton armigerum (Hymenoptera: Formicidae). J Chem Ecol. 1990; 16(4): 1207-19.

PubMed Abstract | Publisher Full Text

10. Gardner A, Foster KR: Chapter 1: The Evolution and Ecology of Cooperation History and Concepts. In Ecol Soc Evol. (Korb J \& Heinze J), Springer, 2008; 1-35. Reference Source

11. Smith JM: Group selection and kin selection. Nature. 1964; 201: 1145-7. Publisher Full Text

12. F West SA, Giffin AS, Gardner A: Social semantics: how useful has group selection been? J Evolution Biol. 2008; 21(1): 374-85

Publisher Full Text | F1000 Recommendation

13. Allen B, Nowak MA, Wilson EO: Limitations of inclusive fitness. Proc Natl Acad SciU S A. 2013; 110(50): 20135-9.

PubMed Abstract | Publisher Full Text | Free Full Text

14. Hamilton WD: The genetical evolution of social behaviour. I. J Theor Biol. 1964 7(1): $1-16$

PubMed Abstract | Publisher Full Text

15. Hamilton WD: The evolution of altruistic behavior. Am Nat. 1963; 97(896): 354-6. Publisher Full Text

16. Hamilton WD: The genetical evolution of social behaviour. II. J Theor Biol. 1964; 7(1): 17-52. PubMed Abstract | Publisher Full Tex

17. F Birch J, Okasha S: Kin selection and its critics. BioScience. 2015; 65(1): 22-32. Publisher Full Text | F1000 Recommendation

18. Gardner A, West SA, Wild G: The genetical theory of kin selection. J Evol Biol. 2011; 24(5): 1020-43. PubMed Abstract | Publisher Full Text

19. West SA, Gardner A: Adaptation and inclusive fitness. Curr Biol. 2013; 23(13) R577-84.

PubMed Abstract | Publisher Full Text
20. Taylor PD, Frank SA: How to make a kin selection model. J Theor Biol. 1996; 180(1): 27-37.

PubMed Abstract | Publisher Full Text

21. Taylor PD, Wild G, Gardner A: Direct fitness or inclusive fitness: how shall we model kin selection? J Evol Biol. 2007; 20(1): 301-9.

PubMed Abstract | Publisher Full Text

22. Marshall JA: Social evolution and inclusive fitness theory. Princeton University Press, 2015.

Reference Source

23. Frank SA: Foundations of social evolution. Princeton University Press, 1998. Reference Sourc

24. Frank SA: Natural selection. VII. History and interpretation of kin selection theory. J Evol Biol. 2013; 26(6): 1151-84. PubMed Abstract | Publisher Full Text

25. Grafen A: Optimization of inclusive fitness. J Theor Biol. 2006; 238(3): 541-63. PubMed Abstract | Publisher Full Text

26. F Grafen A: The formal darwinism project in outline. Biol Philos. 2014; 29(2): $155-74$.

Publisher Full Text | F1000 Recommendation

27. F Okasha S, Weymark JA, Bossert W: Inclusive fitness maximization: an axiomatic approach. $J$ Theor Biol. 2014; 350: 24-31.

PubMed Abstract | Publisher Full Text | F1000 Recommendation

28. Lehmann L, Rousset F: Fitness, inclusive fitness, and optimization. Biol Philos. 2014; 29(2): 181-95

Publisher Full Text

29. F Birch J: Natural selection and the maximization of fitness. Biol Rev Camb Philos Soc. 2015.

PubMed Abstract | Publisher Full Text | F1000 Recommendation

30. F Goodnight C: On multilevel selection and kin selection: contextual analysis meets direct fitness. Evolution. 2013; 67(6): 1539-48. PubMed Abstract | Publisher Full Text | F1000 Recommendation

31. Hamilton WD: Innate social aptitudes of man: an approach from evolutionary genetics. In Biosoc Anthropol. (Fox R), Wiley. 1975; 133-155. Reference Source

32. Michod RE: The theory of kin selection. Annu Rev Ecol Syst. 1982; 13: 23-55. Publisher Full Text

33. Grafen A: A geometric view of relatedness. Oxford Surv Evol Biol. 1985; 2: 28-89. Reference Source

34. Queller DC: A general model for kin selection. Evolution. 1992; 46(2): 376-380 Publisher Full Text

35. F Lehmann L, Rousset F: The genetical theory of social behaviour. Philos Trans R Soc Lond B Biol Sci. 2014; 369(1642): 20130357.

PubMed Abstract | Publisher Full Text | Free Full Text | F1000 Recommendation

36. Hamilton WD: Selfish and spiteful behaviour in an evolutionary model. Nature. 1970; 228(5277): 1218-20.

PubMed Abstract | Publisher Full Text

37. Dawkins R: The selfish gene. Oxford University Press, 1976 Reference Source

38. Gardner A, West SA: Greenbeards. Evolution. 2010; 64(1): 25-38. PubMed Abstract | Publisher Full Text

39. Gardner A, West SA, Barton NH: The relation between multilocus population genetics and social evolution theory. Am Nat. 2007; 169(2): 207-26. PubMed Abstract | Publisher Full Text 
40. Marshall JA: Group selection and kin selection: formally equivalent approaches. Trends Ecol Evol. 2011; 26(7): 325-32. PubMed Abstract | Publisher Full Text

41. Birch J: Hamilton's rule and its discontents. Br J Philos Sci. 2014; 65(2): 381-411. Publisher Full Text

42. Davies N, Krebs JR, West SA: An introduction to behavioural ecology. Fourth Edition, Wiley-Blackwell, 2012.

Reference Source

43. Alcock J: Animal behavior: an evolutionary approach. Sinauer, 2013. Reference Source

44. F Refardt D, Bergmiller T, Kümmerli R: Altruism can evolve when relatedness is low: evidence from bacteria committing suicide upon phage infection. Proc Biol Sci. 2013; 280(1759): 20123035.

PubMed Abstract | Publisher Full Text | Free Full Text | F1000 Recommendation

45. Krakauer $\mathrm{AH}$ : Kin selection and cooperative courtship in wild turkeys. Nature. 2005; 434(7029): 69-72.

PubMed Abstract | Publisher Full Text

46. Bourke AF: Principles of social evolution. Oxford University Press, 2011. Reference Source

47. F Bourke AF: Hamilton's rule and the causes of social evolution. Philos Trans $R$ Soc Lond B Biol Sci. 2014; 369(1642): 20130362 PubMed Abstract | Publisher Full Text | Free Full Text | F1000 Recommendation

48. Okasha S: Evolution and the levels of selection. Oxford University Press, 2006. Publisher Full Text

49. Wilson DS: A theory of group selection. Proc Natl Acad Sci U S A. 1975; 72(1): $143-6$.

PubMed Abstract

50. Goodnight CJ, Schwartz JM, Stevens L: Contextual analysis of models of group selection, soft selection, hard selection, and the evolution of altruism. Am Nat. 1992; 140(5): 743-61.

Publisher Full Text

51. Wade MJ: A critical review of the models of group selection. Q Rev Biol. 1978; 53(2): 101-14 Publisher Full Text

52. Wolf JB, Brodie ED III, Cheverud JM, et al.: Evolutionary consequences of indirect genetic effects. Trends Ecol Evol. 1998; 13(2): 64-9.

PubMed Abstract | Publisher Full Text

53. Bijma $P$, Wade $M J$ : The joint effects of kin, multilevel selection and indirect genetic effects on response to genetic selection. J Evol Biol. 2008; 21(5): 1175-88. PubMed Abstract | Publisher Full Text

54. Stevens L, Goodnight CJ, Kalisz S: Multilevel selection in natural populations of Impatiens capensis. Am Nat. 1995; 145(4): 513-26.

Publisher Full Tex

55. Eldakar OT, Wilson DS, Dlugos MJ, et al.: The role of multilevel selection in the evolution of sexual conflict in the water strider aquarius remigis. Evolution. 2010; 64(11): 3183-9.

PubMed Abstract | Publisher Full Text | Free Full Text

56. F Pruitt JN, Goodnight CJ: Site-specific group selection drives locally adapted group compositions. Nature. 2014; 514(7522): 359-62.

PubMed Abstract | Publisher Full Text | F1000 Recommendation

57. Simon B, Fletcher JA, Doebeli M: Towards a general theory of group selection. Evolution. 2013; 67(6): 1561-72.

PubMed Abstract | Publisher Full Text

58. F Gardner A: The genetical theory of multilevel selection. J Evol Biol. 2015 28(2): 305-19.

PubMed Abstract | Publisher Full Text | Free Full Text | F1000 Recommendation

59. F Goodnight CJ: Multilevel selection theory and evidence: a critique of Gardner, 2015. J Evol Biol. 2015; 28(9): 1734-46.

PubMed Abstract | Publisher Full Text | F1000 Recommendation

60. Gardner A: More on the genetical theory of multilevel selection. J Evol Biol. 2015; 28(9): 1747-51.

PubMed Abstract | Publisher Full Tex

61. Sober E, Wilson DS: Onto others: the evolution and psychology of unselfish behavior. Harvard University Press, 1998 Reference Source

62. Damuth J, Heisler IL: Alternative formulations of multilevel selection. Biol Philos. 1988: 3(4): 407-30. Publisher Full Text

63. Okasha S: Multi-level selection, covariance and contextual analysis. Br J Philos Sci. 2004; 55(3): 481-504.

Publisher Full Tex

64. Mayo DG, Gilinsky NL: Models of group selection. Philos Sci. 1987; 54(4): 515-38.

Publisher Full Text

65. F West SA, Griffin AS, Gardner A: Social semantics: altruism, cooperation, mutualism, strong reciprocity and group selection. J Evol Biol. 2007; 20(2): $415-32$.

PubMed Abstract | Publisher Full Text | F1000 Recommendation

66. Michod RE: On the transfer of fitness from the cell to the multicellular organism. Biol Philos. 2006; 20(5): 967-87.

Publisher Full Tex
67. Okasha S: Multilevel selection and the major transitions in evolution. Philos Sci. 2005; 72(5): 1013-25

Publisher Full Text

68. Shelton DE, Michod RE: Philosophical foundations for the hierarchy of life. Biol Philos. 2010; 25(3): 391-403. Publisher Full Text

69. F Szathmáry E: Toward major evolutionary transitions theory 2.0. Proc Natl Acad Sci U S A. 2015; 112(33): 10104-11.

PubMed Abstract | Publisher Full Text | Free Full Text | F1000 Recommendation

70. Wilson DS: Social semantics: toward a genuine pluralism in the study of social behaviour. J Evol Biol. 2008; 21(1): 368-73.

PubMed Abstract | Publisher Full Text

71. Leigh EG Jr: The group selection controversy. J Evol Biol. 2010; 23(1): 6-19. PubMed Abstract | Publisher Full Text

72. Lion S, Jansen VA, Day T: Evolution in structured populations: beyond the kin versus group debate. Trends Ecol Evol. 2011; 26(4): 193-201.

PubMed Abstract | Publisher Full Text

73. F Kerr B, Neuhauser C, Bohannan BJ, et al:: Local migration promotes competitive restraint in a host-pathogen 'tragedy of the commons'. Nature. 2006; 442(7098): 75-8.

PubMed Abstract | Publisher Full Text | F1000 Recommendation

74. Fehr E, Fischbacher U: The nature of human altruism. Nature. 2003; 425(6960): 785-91.

PubMed Abstract | Publisher Full Text

75. Boyd R, Gintis H, Bowles S, et al:: The evolution of altruistic punishment. Proc Natl Acad Sci U S A. 2003; 100(6): 3531-5.

PubMed Abstract | Publisher Full Text | Free Full Text

76. Borrello ME: Evolutionary restraints. University of Chicago Press; 2010. Reference Source

77. Wynne-Edwards VC: Animal dispersion in relation to social behaviour. Oliver and Boyd, 1962

78. Lorenz K: Das sogenannte Böse. Zur Naturgeschichte der Aggression. Buchgemeinschaft Donauland, 1963.

Reference Source

79. Borrello ME: The rise, fall and resurrection of group selection. Endeavour. 2005; 29(1): 43-7.

PubMed Abstract | Publisher Full Text

80. Maynard-Smith J, Price GR: The logic of animal conflict. Nature. 1973; 246: 15-8. Publisher Full Text

81. Williams GC: Adaptation and natural Selection: a critique of some current evolutionary thought. Princeton University Press, 1966. Reference Source

82. Wilson DS: Structured demes and the evolution of group-advantageous traits. Am Nat. 1977; 111(977): 157-85.

Publisher Full Text

83. Wilson DS: Altruism in mendelian populations derived from sibling groups: the haystack model revisited. Evolution. 1987; 41(5): 1059-1070.

Publisher Full Text

84. Wilson DS: The natural selection of populations and communities. Benjamin-Cumming 980.

Reference Source

85. Wade MJ: An experimental study of group selection. Evolution. 1977; 31(1): 134-153.

Publisher Full Text

86. Craig DM: Group selection versus individual selection: an experimenta analysis. Evolution. 1982; 36(2): 271-282. Publisher Full Text

87. Goodnight CJ: The influence of environmental variation on group and individual selection in a cress. Evolution. 1985; 39(3): 545-558. Publisher Full Text

88. Goodnight CJ, Stevens L: Experimental studies of group selection: what do they tell us about group selection in nature? Am Nat. 1997; 150(Suppl 1): S59-79. PubMed Abstract | Publisher Full Text

89. Shavit A: Shifting values partly explain the debate over group selection. Studies in History and Philosophy of Science Part C: Studies in History and Philosophy of Biological and Biomedical Sciences. 2004; 35(4): 697-720. Publisher Full Text

90. Shavit A, Millstein RL: Group selection is dead! long live group selection. BioScience. 2008; 58(7): 574-575. Publisher Full Text

91. Okasha S: Altruism researchers must cooperate. Nature. 2010; 467: 653-5. Publisher Full Text

92. Pinker S: The false allure of group selection. Edge. 2012. Reference Source

93. Lehmann L, Keller L, West S, et al:: Group selection and kin selection: two concepts but one process. Proc Natl Acad Sci U S A. 2007; 104(16): 6736-9. PubMed Abstract | Publisher Full Text | Free Full Text

94. Queller DC: Quantitative genetics, inclusive fitness, and group selection. Am Nat 1992; 139(3): 540-58. Publisher Full Text

95. van Veelen M, Luo S, Simon B: A simple model of group selection that cannot 
be analyzed with inclusive fitness. $J$ Theor Biol. 2014; 360: 279-89. PubMed Abstract | Publisher Full Text

96. van Veelen M: Group selection, kin selection, altruism and cooperation: when inclusive fitness is right and when it can be wrong. J Theor Biol. 2009; 259(3): 589-600.

PubMed Abstract | Publisher Full Text

97. Traulsen A: Mathematics of kin- and group-selection: formally equivalent? Evolution. 2010; 64(2): 316-23.

PubMed Abstract | Publisher Full Text

98. Simon B: Continuous-time models of group selection, and the dynamical insufficiency of kin selection models. J Theor Biol. 2014; 349: 22-31. PubMed Abstract | Publisher Full Text

99. van Veelen M, García J, Sabelis MW, et al.: Group selection and inclusive fitness are not equivalent; the Price equation vs. models and statistics. $J$ Theor Biol. 2012; 299: 64-80.

PubMed Abstract | Publisher Full Text

100. F Wilson EO, Hölldobler B: Eusociality: origin and consequences. Proc Nat Acad Sci U S A. 2005; 102(38): 13367-71.

PubMed Abstract | Publisher Full Text | F1000 Recommendation

101. F Nowak MA, Tarnita CE, Wilson EO: The evolution of eusociality. Nature. 2010; 466(7310): 1057-62.

PubMed Abstract | Publisher Full Text | Free Full Text | F1000 Recommendation

102. Wilson EO: The social conquest of earth. Liveright, 2012 Reference Source

103. Tekwa EW, Gonzalez A, Loreau M: Local densities connect spatial ecology to game, multilevel selection and inclusive fitness theories of cooperation. $J$ Theor Biol. 2015; 380: 414-25.

PubMed Abstract | Publisher Full Text

104. F Débarre F, Hauert C, Doebeli M: Social evolution in structured populations. Nat Commun. 2014; 5: 3409.

PubMed Abstract | Publisher Full Text | F1000 Recommendation

105. F Griffin AS, West SA, Buckling A: Cooperation and competition in pathogenic bacteria. Nature. 2004; 430 (7003): 1024-7.

PubMed Abstract | Publisher Full Text | F1000 Recommendation

106. Queller DC: Social evolution: kinship is relative. Nature. 2004; 430 (7003): 975-6. PubMed Abstract | Publisher Full Text

107. F Chuang JS, Rivoire O, Leibler S: Simpson's paradox in a synthetic microbial system. Science. 2009; 323(5911): 272-5.

PubMed Abstract | Publisher Full Text | F1000 Recommendation

108. Kümmerli R, Gardner A, West SA, et al.: Limited dispersal, budding dispersal, and cooperation: an experimental study. Evolution. 2009; 63(4): 939-49. PubMed Abstract | Publisher Full Text

109. Sober E, Wilson DS: Adaptation and Natural Selection revisited. J Evol Biol. 2011: 24(2): 462-8. PubMed Abstract | Publisher Full Text

110. Price GR: Selection and covariance. Nature, 1970; 227(5257): 520-1. PubMed Abstract | Publisher Full Text

111. Price GR: Extension of covariance selection mathematics. Ann Hum Genet. 1972; 35(4): 485-90.

PubMed Abstract | Publisher Full Text

112. Wade MJ: Soft selection, hard selection, kin selection, and group selection. Am Nat. 1985; 125(1): 61-73. Publisher Full Text

113. Moorad JA: Multi-level sexual selection: individual and family-level selection for mating success in a historical human population. Evolution. 2013; 67(6): 1635-48.

PubMed Abstract | Publisher Full Text | Free Full Text

114. Weis AE, Turner KM, Petro B et al: Hard and soft selection on phenology through seasonal shifts in the general and social environments: a study on plant emergence time. Evolution. 2015; 69(6): 1361-74. PubMed Abstract | Publisher Full Text

115. Heisler IL, Damuth J: A method for analyzing selection in hierarchically structured populations. Am Nat. 1987; 130(4): 582-602. Publisher Full Text

116. Jeler C: Is there such a thing as "group selection" in the, contextual analysis framework? Hist Philos Life Sci. 2015; 36(4): 484-502. PubMed Abstract | Publisher Full Tex

117. Earnshaw E: Group selection and contextual analysis. Synthese. 2015; 192(1): 305-16.

Publisher Full Text

118. van Veelen M: On the use of the Price equation. J Theor Biol. 2005; 237(4): $412-26$

PubMed Abstract | Publisher Full Text

119. Frank SA: Natural selection. IV. The price equation. J Evol Biol. 2012; 25(6): 1002-19.

PubMed Abstract | Publisher Full Text | Free Full Text

120. Queller DC: Kin selection and frequency dependence: a game theoretic approach. Biological Journal of the Linnean Society. 1984; 23(2-3): 133-43. Publisher Full Tex

121. van Veelen M: A rule is not a rule if it changes from case to case (a reply to
Marshall's comment). J Theor Biol. 2011; 270(1): 189-95 Publisher Full Text

122. Marshall JA: Queller's rule ok: comment on van Veelen 'when inclusive fitness is right and when it can be wrong'. J Theor Biol. 2011; 270(1): 185-8; author reply 189-95.

PubMed Abstract | Publisher Full Text

123. Birch J, Marshall JA: Queller's separation condition explained and defended. Am Nat. 2014: 184(4): 531-40.

PubMed Abstract | Publisher Full Text

124. Nowak MA, Allen B: Inclusive fitness theorizing invokes phenomena that are not relevant for the evolution of eusociality. PLOS Biol. 2015; 13(4): e1002134. PubMed Abstract | Publisher Full Text | Free Full Text

125. Nowak MA, Tarnita CE, Wilson EO: Nowak et al. reply. Nature. 2011; 471: E9-E10. Publisher Full Text

126. Abbot $\mathrm{P}, \mathrm{Abe} \mathrm{J}$, Alcock J, et al:: Inclusive fitness theory and eusociality. Nature. 2011; 471(7339): E1-4; author reply E9-10. PubMed Abstract | Publisher Full Text | Free Full Tex

127. F Bourke AF: Sex investment ratios in eusocial Hymenoptera support inclusive fitness theory. J Evol Biol. 2015; 28(11): 2106-11. PubMed Abstract | Publisher Full Text | F1000 Recommendation

128. Liao X, Rong S, Queller DC: Relatedness, conflict, and the evolution of eusociality. PLOS Biol. 2015; 13(3): e1002098. PubMed Abstract | Publisher Full Text | Free Full Tex

129. F Simon B, Fletcher JA, Doebeli M: Hamilton's rule in multi-level selection models. J Theor Biol. 2012; 299: 55-63. PubMed Abstract | Publisher Full Text | F1000 Recommendation

130. Gordon DM: The rewards of restraint in the collective regulation of foraging by harvester ant colonies. Nature. 2013; 498(7452): 91-3. PubMed Abstract | Publisher Full Text

131. Muir WM: Group selection for adaptation to multiple-hen cages: selection program and direct responses. Poult Sci. 1996; 75(4): 447-58. PubMed Abstract | Publisher Full Text

132. Eldakar OT, Dlugos MJ, Pepper JW, et al:: Population structure mediates sexual conflict in water striders. Science. 2009; 326(5954): 816. PubMed Abstract | Publisher Full Text

133. $\mathrm{F}$ Smallegange IM, Egas M: Good for the group? Explaining apparent group-leve adaptation. Trends Ecol Evol. 2015; 30(7): 379-81. PubMed Abstract | Publisher Full Text | F1000 Recommendation

134. Grinsted L, Bilde T, Gilbert JD: Questioning evidence of group selection in spiders. Nature. 2015; 524(7566): E1-3. PubMed Abstract | Publisher Full Text

135. Gardner A: Group selection versus group adaptation. Nature. 2015; 524(7566): E3-4. PubMed Abstract | Publisher Full Text

136. Gardner A, Grafen A: Capturing the superorganism: a formal theory of group adaptation. J Evol Biol. 2009; 22(4): 659-71. PubMed Abstract | Publisher Full Text

137. Okasha S, Paternotte C. Group adaptation, formal darwinism and contextual analysis. J Evol Biol. 2012; 25(6): 1127-39. PubMed Abstract | Publisher Full Text

138. Akçay $\mathrm{E}$, van Cleve J: Behavioral responses in structured populations pave the way to group optimality. Am Nat. 2012; 179(2): 257-69. PubMed Abstract | Publisher Full Text

139. Kokko H, Heubel KU: Prudent males, group adaptation, and the tragedy of the commons. Oikos. 2011; 120(5): 641-56. Publisher Full Text

140. Frank SA: Perspective: repression of competition and the evolution of cooperation. Evolution. 2003; 57(4): 693-705. PubMed Abstract | Publisher Full Text

141. Leigh EG: How does selection reconcile individual advantage with the good of the group? Proc Natl Acad Sci U S A. 1977; 74(10): 4542-6. PubMed Abstract | Publisher Full Text | Free Full Text

142. Wenseleers T, Ratnieks FL: Enforced altruism in insect societies. Nature. 2006; 444(7115): 50 PubMed Abstract | Publisher Full Text

143. Pruitt JN, Goodnight CJ: Pruitt \& Goodnight reply. Nature. 2015; 524(7566): E4-5. PubMed Abstract | Publisher Full Text

144. O'Gorman R, Sheldon KM, Wilson DS: For the good of the group?: exploring group-level evolutionary adaptations using multilevel selection theory. Group Dyn Theor Res. 2008; 12(1): 17-26. Publisher Full Text

145. Gardner A: Adaptation as organism design. Biol Lett. 2009; 5(6): 861-4. PubMed Abstract | Publisher Full Text | Free Full Text

146. Mlot NJ, Tovey CA, Hu DL: Fire ants self-assemble into waterproof rafts to survive floods. Proc Natl Acad Sci U S A. 2011; 108(19): 7669-73. PubMed Abstract | Publisher Full Text | Free Full Text

147. Queller DC, Strassmann JE: Beyond society: the evolution of organismality. Philos Trans R Soc Lond B Biol Sci. 2009; 364(1533): 3143-55. PubMed Abstract | Publisher Full Text | Free Full Text 
148. Seeley TD: Honey bee colonies are group-level adaptive units. Am Nat. 1997; 150(Suppl 1): S22-41.

PubMed Abstract | Publisher Full Text

149. F Bourke AF: The validity and value of inclusive fitness theory. Proc Biol Sci. 2011; 278(1723): 3313-20.

PubMed Abstract | Publisher Full Text | Free Full Text | F1000 Recommendation

150. F Okasha S: The relation between kin and multilevel selection: an approach using causal graphs. Br J Philos Sci. 2015.

Publisher Full Text | F1000 Recommendation
151. Wilson EO, Nowak MA: Natural selection drives the evolution of ant life cycles. Proc Natl Acad Sci U S A. 2014; 111(35): 12585-90. PubMed Abstract | Publisher Full Text | Free Full Text

152. Kümmerli R, van den Berg P, Griffin AS, et al:: Repression of competition favours cooperation: experimental evidence from bacteria. J Evol Biol. 2010; 23(4): 699-706

PubMed Abstract | Publisher Full Text

153. Chuang JS, Rivoire O, Leibler S: Cooperation and Hamilton's rule in a simple synthetic microbial system. Mol Syst Biol. 2010; 6(1): 398.

PubMed Abstract | Publisher Full Text | Free Full Text 


\section{Open Peer Review}

\section{Current Peer Review Status:}

\section{Editorial Note on the Review Process}

Faculty Reviews are review articles written by the prestigious Members of Faculty Opinions. The articles are commissioned and peer reviewed before publication to ensure that the final, published version is comprehensive and accessible. The reviewers who approved the final version are listed with their names and affiliations.

\section{The reviewers who approved this article are:}

\section{Version 1}

\section{Heikki Helanterä}

University of Helsinki, Helsinki, Finland

Competing Interests: No competing interests were disclosed.

\section{Jonathan Pruitt}

University of Pittsburgh, Pittsburgh, PA, USA

Competing Interests: No competing interests were disclosed.

\section{Rolf Kümmerli}

University of Zürich, Zürich, Switzerland

Competing Interests: No competing interests were disclosed.

\section{James Marshall}

University of Sheffield, Sheffield, South Yorkshire, UK

Competing Interests: No competing interests were disclosed.

The benefits of publishing with F1000Research:

- Your article is published within days, with no editorial bias

- You can publish traditional articles, null/negative results, case reports, data notes and more

- The peer review process is transparent and collaborative

- Your article is indexed in PubMed after passing peer review

- Dedicated customer support at every stage

For pre-submission enquiries, contact research@f1000.com 